\title{
UJI GABUNGAN PERTUMBUHAN JARAK PAGAR AKIBAT PEMBERIAN FMA DAN SITOKININ DI DUA LOKASI BERBEDA
}

\author{
Disusun oleh: \\ Kovertina Rakhmi Indriana \\ Fakultas Pertanian-Universitas Winaya Mukti, Jl. Raya Bandung - Sumedang Km.29 \\ Tanjungsari 45362, Kab. Sumedang, Jawa Barat, Indonesia. \\ Email : kovertina.rakhmi.indriana@gmail.com
}

\begin{abstract}
Abstrak
Tujuan penelitian ini untuk mengungkapkan hasil pertumbuhan tanaman terbaik melalui uji gabungan multi lokasi dengan memberikan kombinasi tiga kultivar jarak pagar dan dosis fungi mikoriza arbuskular (FMA) terbaik dengan konsentrasi sitokinin pada lahan marginal seperti tanah inceptisol. Percobaan dimulai bulan Januari 2019 sampai bulan Juni 2019 pada ketinggian 0-50 mdpl (dataran rendah) dan ketinggian 750-850 mdpl (dataran menengah). Percobaan kombinasi mengevaluasi kultivar jarak pagar dengan dosis FMA terbaik dan konsentrasi sitokinin diulang 3 kali. Hasil percobaan terdapat pengaruh yang nyata dan interaksi antara sitokinin dan kultivar jarak pagar dengan dosis FMA terbaik maka dapat ditentukan kombinasi terbaik antara sitokinin dan kultivar jarak pagar dengan dosis FMA terbaik di kedua lokasi yaitu pada konsentrasi sitokinin $100 \mathrm{mg} \mathrm{L}^{-1}$ untuk rata-rata laju asimilasi bersih (LAB), konsentrasi sitokinin $300 \mathrm{mg} \mathrm{L}^{-1}$ untuk luas daun, nisbah luas daun, dan nisbah pupus akar. Serta konsentrasi sitokinin $400 \mathrm{mg} \mathrm{L}^{-1}$ untuk rata-rata laju tumbuh (LTR).
\end{abstract}

Kata Kunci : Fungi Mikoriza Arbuskula, Jarak Pagar, Kultivar, Sitokinin.

\begin{abstract}
The purpose of this study was to reveal the best plant growth results through a multi-location combined test by providing a combination of three Jatropha cultivars and the best dose of arbuscular mycorrbizal fungi (FMA) with cytokinin concentrations in marginal land such as inceptisol soil. The experiment began in January 2019 until June 2019 at an altitude of 0-50 meters above sea level (lowlands) and altitudes of 750-850 above sea level (medium plains). A combined trial evaluating Jatropha cultivars with the best FMA dose and cytokinin concentrations was repeated 3 times. The results of the experiment have a real influence and interaction between cytokinins and Jatropha cultivars with the best FMA dose, so it can be determined the best combination between cytokinins and Jatropha cultivars with the best FMA doses in both locations at the concentration of cytokinin $100 \mathrm{mg} \mathrm{L}^{-1}$ for the average rate clean assimilation (LAB), cytokinin concentration of $300 \mathrm{mg} \mathrm{L}^{-1}$ for leaf area, leaf area ratio, and root absent ratio. As well as cytokinin concentrations of $400 \mathrm{mg} \mathrm{L}^{-1}$ for average growth rate (LTR).
\end{abstract}

Keywords: Arbuscular Mycorrbizal Fungi, Jatropha Curcass, Cultivars, Cytokines. 


\section{PENDAHULUAN}

Pengembangan tanaman jarak sebagai tanaman alternative konversi BBM ke BBN selayaknya tidak berkompetensi dalam pemanfaatan lahan dengan program ketahanan badan keamanan pangan nasional, karena sebagian besar lahan yang sesuai tersebut sudah digunakan untuk komoditas lain atau untuk sektor non pertanian. Oleh sebab itu penanaman jarak pagar sebaiknya diarahkan pada lahan-lahan marjinal, yaitu tanah yang ketersediaan air dan unsur haranya terbatas (Mulyani, et al., 2008). Salah satu jenis tanah marjinal adalah Inceptisol, dengan faktor pembatas kesuburan kimia tanah rendah, terutama unsur P. Unsur P dapat menjadi tersedia untuk tanaman dengan bantuan FMA.

Simbiosis mutualisme yang saling menguntungkan antara akar tumbuhan dan fungi yang mengoloni hingga ke korteks akar disebut mikoriza (Brundrett et al., 1996). Mikoriza merupakan asosiasi mutualistik antara jamur dengan akar tumbuhan tingkat tinggi (Smith dan Read, 2008). Manfaat FMA dapat dikelompokkan menjadi dua, yaitu manfaat dalam ekosistem, dan manfaat bagi tanaman. Fungsi mikoriza khususnya FMA berfungsi meningkatkan efektivitas penyerapan air oleh tanaman karena dengan adanya hifa-hifa dari mikoriza tersebut yang membatu penyerapan air di dalam tanah. FMA juga menambah unsure hara pada tanaman karena simbiosis yang terjadi antara FMA dan tanaman yaitu FMA mendapatkan unsure karbon hasil dari fotosintesis tanaman dan tanaman mendapatkan unsure hara dari eksudat akar oleh FMA. FMA juga sebagai agen hayati mampu mensekresi unsur $\mathrm{P}$ di dalam tanah, dimana $\mathrm{P}$ terikat dapat menjadi $\mathrm{P}$ tersedia di dalam tanah dengan bantuan sekresi enzim fosfatase. dan 16 asam-asam organik, khususnya asam oksalat yang dapat membantu membebaskan P (Novriani dan Madjid, 2010). Preston, 2007 dalam Suherman, 2011 menyatakan bahwa fungi mikoriza juga dapat menghasilkan hormon seperti auxin, sitokinin, giberellin, juga vitamin juga dilaporkan sebagai hasil metabolisme fungi mikoriza (Anas, 1997).

Sitokinin itu sendiri merupakan zat pengatur tumbuh BAP (Bensyl Adenin Purine) dengan zat aktifnya kinetin. Pertumbuhan ujung batang sering mendominasi pertumbuhan oragn tanaman lain oleh karena nya pertumbuhan cabang lateral bisa di hambat atau disebut dengan peristiwa dominasi apical.

Dominansi apical dan pembentukan cabang lateral ini dipengaruhi oleh keseimbangan konsentrasi hormone (Hopkins, 1995).

Sitokinin dapat mematahkan dormansi apical cabang tanaman sehingga tajuk tanaman menjadi lebih produktif. Pemberian sitokinin pada tanaman jarak pagar pada prinsipnya bertujuna untuk mengatur keseimbangan hormone sitokinin dan auksin di ketiak daun dimana cabang tanaman jarak muncul di ketiak daun cabang (Taiz and Zeiger, 2006 dan Hopkins, 1995).

\section{METODE PENELITIAN}

Bahan yang digunakan pada percobaan ini adalah benih jarak kultivar IP-3P (Improve Population 3 Pakuwon), IP-3A (Improve Population 3 Asembagus), IP-3M (Improve Population 3 Muktiharjo), FMA Konsorsium (Glomus sp. Gigaspora sp. Acaulospora sp.) (Cucu Suherman, 2011), sitokinin (BAP), pupuk kandang, pupuk kimia yang digunakan adalah pupuk Urea $(45 \% \mathrm{~N})$, SP-36 (36\% $\left.\mathrm{P}_{2} \mathrm{O}_{5}\right), \mathrm{KCl}\left(60 \% \mathrm{~K}_{2} \mathrm{O}\right)$, dan fungisida Dithane M-45.

Percobaan dilaksanakan di dataran rendah Cirebon (0-50 mdpl) dan dataran menengah Jatinangor $(750-850 \mathrm{mdpl})$ berdasarkan ketinggian tempatnya, memiliki ordo tanah Inceptisol dan tipe curah hujan termasuk C (Schmidt dan Ferguson, 1951). Waktu percobaan dimulai dari bulan November 2017 sampai bulan September 2018.

Rancangan percobaan yang digunakan adalah Rancangan Acak Kelompok (RAK) pola faktorial yang terdiri dari dua faktor, yaitu faktor 
pertama tiga taraf dosis FMA terbaik setiap kultivar jarak pagar, untuk wilayah dataran rendah dosis konsorsium FMA untuk kultivar IP-3P : $5 \mathrm{~g}$, IP-3A : $5 \mathrm{~g}$, IP$3 \mathrm{M}: 10$ g. Untuk wilayah dataran menengah dosis konsorsium FMA untuk kultivar IP-3P : $10 \mathrm{~g}$, IP-3A : $5 \mathrm{~g}$, IP-3M : 10 g. Faktor kedua lima taraf konsentrasi sitokinin yaitu $0 \mathrm{mg} \mathrm{L}^{-1}, 100 \mathrm{mg} \mathrm{L}^{-1}, 200$ mg L-1, $300 \mathrm{mg} \mathrm{L}^{-1}, 400 \mathrm{mg} \mathrm{L}^{-1}$. Jumlah kombinasi perlakuan 15 yang diulang 3 kali, sehingga ada 45 petak percobaan di masing-masing lokasi. Penempatan perlakuan pada tiap ulangan dilakukan secara acak.

Data yang didapatkan dianalisis secara statistic menggunakan analisis varians dengan uji $\mathrm{F}$ pada taraf 5\% dan uji lanjut Duncan's Multiple Range Test (DMRT) pada taraf 5\%. Efek daya gabung diestimasi dengan rumus Griffing Meode (Singh dan Chaudhary, 1979).

\section{HASIL DAN PEMBAHASAN}

\section{Karakteristik Tumbuh Tanaman \\ a. Luas Daun}

Hasil analisis menunjukkan bahwa terdapat perbedaan yang sangat nyata untuk variabel luas daun pada masingmasing dosis sitokinin BAP, selain itu terjadi interaksi antara sitokinin BAP dan lokasi, sitokinin dan kultivar jarak pagar dengan dosis FMA terbaik, dan sitokinin BAP ; lokasi ; kultivar jarak pagar dengan dosis FMA terbaik. Hasil analisis menunjukkan bahwa koefisien keragaman 0,19\% merujuk pada Harjosuwono, dkk. (2011:12) apabila koefisien keragaman di bawah $20 \%$ maka data dapat dipertanggungjawabkan.

Tabel 1. Hasil Analsis Sidik Ragam Terhadap Luas Daun $\left(\mathrm{cm}^{2}\right)$ Yang Di Tanam Di Kedua Wilayah Berbeda Berdasarkan Ketinggian Tempat Berbeda.

\begin{tabular}{|c|c|c|c|c|c|c|}
\hline \multirow{2}{*}{ Sumber } & \multirow{2}{*}{$\mathrm{db}$} & \multirow{2}{*}{ JK } & \multirow{2}{*}{ KT } & \multirow{2}{*}{ FHitung } & \multicolumn{2}{|c|}{ FTabel } \\
\hline & & & & & $5 \%$ & $1 \%$ \\
\hline Lokasi & 1 & $8,274.25$ & $8,274.25$ & $115.02 * *$ & 4.75 & 9.33 \\
\hline Aplikasi & 2 & $408,398.90$ & $204,199.45$ & $2,838.52 * *$ & 3.89 & 6.93 \\
\hline Lokasi*Aplikasi & 2 & $108,426.88$ & $54,213.44$ & $753.61 * *$ & 3.89 & 6.93 \\
\hline Ulangan*Lokasi*Aplikasi & 12 & 863.27 & 71.94 & $400.04 * *$ & 1.96 & 2.58 \\
\hline Hormon & 4 & $204,924.23$ & $51,231.06$ & $284,887.37 * *$ & 2.57 & 3.74 \\
\hline Hormon*Lokasi & 4 & $141,810.66$ & $35,452.67$ & $197,146.36^{* *}$ & 2.57 & 3.74 \\
\hline Hormon*Aplikasi & 8 & $252,533.78$ & $31,566.72$ & $175,537.28^{* *}$ & 2.14 & 2.91 \\
\hline Hormon*Lokasi*Aplikasi & 8 & $83,574.42$ & $10,446.80$ & $58,092.93^{* *}$ & 2.14 & 2.91 \\
\hline Galat & 48 & 8.63 & 0.18 & & & \\
\hline Total Terkoreksi & 89 & $1,208,815.02$ & & & & \\
\hline
\end{tabular}

Tabel 2. Rata-rata Luas Daun $\left(\mathrm{cm}^{2}\right)$ Masing-masing Perlakuan Yang Di Tanam Di Kedua Wilayah Berbeda Berdasarkan Ketinggian Tempat Berbeda.

\begin{tabular}{|c|c|c|c|c|c|c|c|c|c|}
\hline \multirow{2}{*}{$\begin{array}{l}\text { Hor } \\
\text { mon }\end{array}$} & \multicolumn{3}{|c|}{ Cirebon } & \multirow{2}{*}{$\begin{array}{c}\text { Rerata } \\
\text { Hormon } \\
\text { (Lokasi } \\
\text { 1) }\end{array}$} & \multicolumn{3}{|c|}{ Jatinangor } & \multirow{2}{*}{$\begin{array}{c}\text { Rerata } \\
\text { Hormon } \\
\text { (Lokasi } \\
2)\end{array}$} & \multirow{2}{*}{$\begin{array}{c}\text { Rerata } \\
\text { Hormon } \\
(\mathbf{M} 1+\mathbf{M})\end{array}$} \\
\hline & $\mathbf{X}_{1}$ & $\mathrm{X}_{2}$ & $\mathrm{X}_{3}$ & & $\mathbf{X}_{1}$ & $\mathbf{X}_{2}$ & $\mathrm{X}_{3}$ & & \\
\hline $\mathrm{S}_{0}$ & $169.63^{\mathrm{ij}}$ & $142.90^{j}$ & $199.04^{\mathrm{h}}$ & $170.52^{\mathrm{h}}$ & $140.86^{\mathrm{kl}}$ & $339.62^{\mathrm{e}}$ & $352.50^{c}$ & $277.66^{c}$ & $224.09^{d}$ \\
\hline $\mathrm{S}_{1}$ & $211.91^{\mathrm{h}}$ & $219.73^{\mathrm{h}}$ & $314.57^{f}$ & $248.74^{\mathrm{d}}$ & $135.66^{\mathrm{m}}$ & $200.41^{\mathrm{h}}$ & $290.38 \mathrm{~g}$ & $208.82^{f}$ & $228.78^{c}$ \\
\hline $\mathrm{S}_{2}$ & $163.60^{\mathrm{ij}}$ & $67.41 \mathrm{q}$ & $146.73^{1}$ & $125.91^{i}$ & $104.49^{\circ}$ & $240.66^{\mathrm{gh}}$ & $123.47^{n}$ & $156.21^{\mathrm{i}}$ & $141.06^{\mathrm{e}}$ \\
\hline $\mathrm{S}_{3}$ & $165.24^{\mathrm{ij}}$ & $140.14^{1}$ & $605.09^{a}$ & $303.49^{\mathrm{b}}$ & 73.99p & $178.36^{\mathrm{i}}$ & $313.46^{\mathrm{f}}$ & $188.60 \mathrm{~g}$ & $246.05^{\mathrm{b}}$ \\
\hline $\mathrm{S}_{4}$ & $250.85^{\mathrm{gh}}$ & $252.45^{\mathrm{gh}}$ & $476.38^{b}$ & $326.56^{a}$ & $142.13^{j \mathrm{k}}$ & $257.83^{\mathrm{gh}}$ & $344.19^{d}$ & $248.05^{\mathrm{e}}$ & $287.31^{\mathrm{a}}$ \\
\hline $\mathrm{S}_{0}$ & $155.25^{\mathrm{k}}$ & $241.26^{f}$ & $275.77^{d}$ & & & & & & \\
\hline $\mathrm{S}_{1}$ & $173.79^{\mathrm{i}}$ & $210.07 \mathrm{~g}$ & $302.47 \mathrm{c}$ & & & & & & \\
\hline $\mathrm{S}_{2}$ & $134.04^{\mathrm{n}}$ & $154.04^{1}$ & $135.10^{\mathrm{m}}$ & & & & & & \\
\hline $\mathrm{S}_{3}$ & $119.62^{\circ}$ & $159.25^{j}$ & $459.28^{a}$ & & & & & & \\
\hline $\mathrm{S}_{4}$ & $196.49^{h}$ & $255.14^{\mathrm{e}}$ & $410.28^{b}$ & & & & & & \\
\hline
\end{tabular}


Awal pertumbuhan luas daun yang ada menangkap cahaya matahari untuk proses fotosintesis secara optimal, namun demikian ketika jumlah daun semakin banyak, tetapi tumbuh saling menutupi, maka luas daun menjadi berkurang. Fungsi daun antara lain tempat pertukaran gas antara jaringan mesofil dan atmosfir. Di dalam daun juga terdapat kloroplas tempat berlangsungnya fotosintesis.

Dari hasil uji lanjut menunjukkan bahwa dosis $\mathrm{S}_{4}\left(400 \mathrm{mg} \mathrm{L}^{-1}\right)$ menunjukkan nilai luas daun yang paling tinggi dibanding dengan dosis lainnya. Perlakuan terbaik ada di lokasi Cirebon dengan nilai luas daun mencapai 326,56 $\mathrm{cm}^{2}$ (Tabel 2). Dari hasil analisis menunjukkan bahwa perlakuan terbaik ada pada sitokinin BAP $\mathrm{S}_{3}(300 \mathrm{mg}$ $\mathrm{L}^{-1}$ ) dan kultivar jarak pagar IP-3M dengan dosis FMA 10 gram di lokasi Cirebon $\left(605,09 \mathrm{~cm}^{2}\right)$. Di karenakan terdapat interaksi antara sitokinin BAP dan kultivar jarak pagar dengan dosis FMA terbaik maka dapat ditentukan kombinasi terbaik antara sitokinin BAP dan kultivar jarak pagar dengan dosis FMA terbaik yaitu pada
$\mathrm{S}_{3}\left(300 \mathrm{mg} \mathrm{L}^{-1}\right)$ dengan $\mathrm{X}_{3}$ (kultivar IP-3M dengan dosis FMA terbaik).

\section{b. Nisbah Luas Daun (NLD)}

Nisbah luas daun merupakan suatu variabel pertumbuhan yang dapat disunakan untuk mencerminkan morfologi tanaman yang berhubungan dengan kedudukan daun. Hasil analisis menunjukkan bahwa terdapat perbedaan yang sangat nyata untuk variabel nisbah luas daun pada masing-masing dosis sitokinin BAP, selain itu terjadi interaksi antara sitokinin BAP dan lokasi, sitokinin dan kultivar jarak pagar dengan dosis FMA terbaik, dan sitokinin BAP ; lokasi ; kultivar jarak pagar dengan dosis FMA terbaik. Hasil analisis menunjukkan bahwa koefisien keragaman sangat rendah yaitu hanya $0,13 \%$ merujuk pada Harjosuwono, dkk. (2011:12) apabila koefisien keragaman di bawah 20\% maka data dapat dipertanggungjawabkan. Hal itu menunjukkan bahwa data variabel nisbah luas daun memiliki tingkat eror yang rendah.

Tabel 3. Hasil Analsis Sidik Ragam Terhadap Nisbah Luas Daun $\left(\mathrm{cm}^{-2} \mathrm{~g}^{-1}\right)$ Yang Di Tanam Di Kedua Wilayah Berbeda Berdasarkan Ketinggian Tempat Berbeda.

\begin{tabular}{|c|c|c|c|c|c|c|}
\hline \multirow{2}{*}{ Sumber } & \multirow{2}{*}{$\mathrm{db}$} & \multirow{2}{*}{ JK } & \multirow{2}{*}{ KT } & \multirow{2}{*}{ FHitung } & \multicolumn{2}{|c|}{ FTabel } \\
\hline & & & & & $5 \%$ & $1 \%$ \\
\hline Lokasi & 1 & $7,495.91$ & $7,495.91$ & $2,993.24 * *$ & 4.75 & 9.33 \\
\hline Aplikasi & 2 & 709.98 & 354.99 & $141.75^{* *}$ & 3.89 & 6.93 \\
\hline Lokasi*Aplikasi & 2 & $1,384.73$ & 692.36 & $276.47 * *$ & 3.89 & 6.93 \\
\hline Ulangan*Lokasi*Aplikasi & 12 & 30.05 & 2.5 & $388.53 * *$ & 1.96 & 2.58 \\
\hline Hormon & 4 & 549.41 & 137.35 & $21,309.73^{* *}$ & 2.57 & 3.74 \\
\hline Hormon*Lokasi & 4 & $1,298.35$ & 324.59 & $50,358.32^{* *}$ & 2.57 & 3.74 \\
\hline Hormon*Aplikasi & 8 & $3,961.37$ & 495.17 & $76,823.76^{* *}$ & 2.14 & 2.91 \\
\hline Hormon*Lokasi*Aplikasi & 8 & $1,433.57$ & 179.2 & $27,801.44 * *$ & 2.14 & 2.91 \\
\hline Galat & 48 & 0.31 & 0.01 & & & \\
\hline Total Terkoreksi & 89 & $16,863.68$ & & & & \\
\hline
\end{tabular}


Tabel 4. Rata-rata Nisbah Luas Daun $\left(\mathrm{cm}^{-2} \mathrm{~g}^{-1}\right)$ Masing-masing Perlakuan Yang Di Tanam Di Kedua Wilayah Berbeda Berdasarkan Ketinggian Tempat Berbeda.

\begin{tabular}{|c|c|c|c|c|c|c|c|c|c|}
\hline \multirow[b]{2}{*}{$\begin{array}{l}\text { Hor } \\
\text { mon }\end{array}$} & \multicolumn{3}{|c|}{ Cirebon } & \multirow{2}{*}{$\begin{array}{c}\text { Rerata } \\
\text { Hormon } \\
\text { (Lokasi } \\
\text { 1) }\end{array}$} & \multicolumn{3}{|c|}{ Jatinangor } & \multirow{2}{*}{$\begin{array}{c}\text { Rerata } \\
\text { Hormon } \\
\text { (Lokasi } \\
2)\end{array}$} & \multirow[b]{2}{*}{$\begin{array}{l}\text { Rerata } \\
\text { Hormon } \\
(\mathbf{M} 1+\mathbf{M})\end{array}$} \\
\hline & $\mathbf{X}_{1}$ & $\mathbf{X}_{2}$ & $\mathbf{X}_{3}$ & & $\mathbf{X}_{1}$ & $\mathbf{X}_{2}$ & $\mathbf{X}_{3}$ & & \\
\hline $\mathrm{S}_{0}$ & $58.12^{\mathrm{m}}$ & $57.48^{\mathrm{n}}$ & $47.78^{\circ}$ & $54.46^{\mathrm{f}}$ & $64.48^{\mathrm{i}}$ & $82.05^{c}$ & $76.40^{\mathrm{d}}$ & $74.31^{\mathrm{a}}$ & $64.38^{a}$ \\
\hline $\mathrm{S}_{1}$ & $53.62^{\mathrm{n}}$ & $42.45 \mathrm{q}$ & $65.45^{\mathrm{h}}$ & $53.84^{\mathrm{g}}$ & $58.20^{\mathrm{m}}$ & $62.67 i$ & $59.46^{1}$ & $60.11^{\mathrm{e}}$ & $56.97 \mathrm{~d}$ \\
\hline $\mathrm{S}_{2}$ & $48.71^{\circ}$ & $38.05^{\mathrm{s}}$ & $49.81^{\text {no }}$ & $45.52^{\mathrm{j}}$ & $62.88^{j}$ & $91.26^{\mathrm{a}}$ & $66.71^{\mathrm{g}}$ & $73.62^{\mathrm{b}}$ & $59.57^{\mathrm{b}}$ \\
\hline $\mathrm{S}_{3}$ & $45.71^{\mathrm{p}}$ & $62.15^{\mathrm{k}}$ & $33.05^{t}$ & $46.97^{\mathrm{i}}$ & $58.27^{\mathrm{m}}$ & $88.00^{\mathrm{b}}$ & $64.50^{\mathrm{i}}$ & $70.26^{c}$ & $58.61^{c}$ \\
\hline $\mathrm{S}_{4}$ & $48.03^{\circ}$ & $41.22^{\mathrm{r}}$ & $68.77^{f}$ & $52.67^{\mathrm{h}}$ & $62.31^{\mathrm{k}}$ & $62.18^{\mathrm{k}}$ & $74.81^{\mathrm{e}}$ & $66.43^{\mathrm{d}}$ & $59.55^{\mathrm{b}}$ \\
\hline $\mathrm{S}_{0}$ & $61.30 \mathrm{~g}$ & $69.77^{c}$ & $62.09^{f}$ & & & & & & \\
\hline $\mathrm{S}_{1}$ & $55.91^{\mathrm{i}}$ & $52.56^{\mathrm{k}}$ & $62.46^{\mathrm{e}}$ & & & & & & \\
\hline $\mathrm{S}_{2}$ & $55.79^{\mathrm{i}}$ & $64.66^{\mathrm{d}}$ & $58.26^{\mathrm{h}}$ & & & & & & \\
\hline $\mathrm{S}_{3}$ & $51.99^{1}$ & $75.08^{a}$ & $48.78^{n}$ & & & & & & \\
\hline $\mathrm{S}_{4}$ & $55.17^{i}$ & $51.70^{\mathrm{m}}$ & $71.79^{\mathrm{b}}$ & & & & & & \\
\hline
\end{tabular}

Dari hasil uji lanjut menunjukkan bahwa dosis $\mathrm{S}_{0}\left(0 \mathrm{mg} \mathrm{\textrm {L } ^ { - 1 }}\right)$ menunjukkan nilai nisbah luas daun yang paling tinggi dibanding dengan dosis lainnya. Perlakuan terbaik ada di lokasi Jatinangor dengan nilai nisbah luas daun mencapai 74,31 $\mathrm{cm}^{2} \mathrm{~g}^{-1}$ (Tabel 4). Dari hasil analisis menunjukkan bahwa perlakuan terbaik ada pada sitokinin BAP $\mathrm{S}_{2}\left(200 \mathrm{mg} \mathrm{L}^{-1}\right)$ dan kultivar jarak pagar IP-3A dengan dosis FMA 5 gram di lokasi Jatinangor $\left(91,26 \mathrm{~cm}^{2} \mathrm{~g}^{-1}\right)$. Hal ini disebabkan apabila nisbah luas daun pertanaman menurun maka bobot kering tanaman semakin meningkat (Rahmawaty dkk., 2015). Daun-daun muda bertindak sebagai limbung menggunakan kembali hasil kegiatan fotosintesis untuk pertumbuhan dan perkembangannya (Gardener dkk., 1991). Di karenakan terdapat interaksi antara sitokinin BAP dan kultivar jarak pagar dengan dosis FMA terbaik maka dapat ditentukan kombinasi terbaik antara sitokinin BAP dan kultivar jarak pagar dengan dosis FMA terbaik yaitu pada $\mathrm{S}_{3}\left(300 \mathrm{mg} \mathrm{L}^{-1}\right)$ dengan $\mathrm{X}_{2}$ (kultivar IP-3M dengan dosis FMA terbaik).

\section{c. Rata-rata Laju Tumbuh Relatif (LTR) \\ Laju tumbuh relatif yaitu laju} penambahan bahan kering total tanaman per bahan kering tertentu per satuan waktu tertentu yang menggambarkan peningkatan bobot kering total per bobot kering tertentu pada periode waktu tertentu. Hasil analisis menunjukkan bahwa terdapat perbedaan yang sangat nyata untuk variabel laju tumbuh relatif pada masing-masing dosis sitokinin BAP, selain itu terjadi interaksi antara sitokinin BAP dan lokasi, sitokinin dan kultivar jarak pagar dengan dosis FMA terbaik, dan sitokinin BAP ; lokasi ; kultivar jarak pagar dengan dosis FMA terbaik. Hasil analisis menunjukkan bahwa koefisien keragaman 3,46\% merujuk pada Harjosuwono, dkk. (2011:12) apabila koefisien keragaman di bawah 20\% maka data dapat dipertanggungjawabkan karena memiliki tingkat eror yang rendah. 
Tabel 5. Hasil Analsis Sidik Ragam Terhadap Laju Tumbuh Relatif ( $\mathrm{g} \mathrm{g}^{-1}$ minggu $\left.^{-1}\right)$ Yang Di Tanam Di Kedua Wilayah Berbeda Berdasarkan Ketinggian Tempat Berbeda.

\begin{tabular}{|c|c|c|c|c|c|c|}
\hline \multirow{2}{*}{ Sumber } & \multirow{2}{*}{$\mathrm{db}$} & \multirow{2}{*}{ JK } & \multirow{2}{*}{ KT } & \multirow{2}{*}{ FHitung } & \multicolumn{2}{|c|}{ FTabel } \\
\hline & & & & & $5 \%$ & $1 \%$ \\
\hline Lokasi & 1 & 0.01 & 0.01 & $0.00^{\mathrm{tn}}$ & 4.75 & 9.33 \\
\hline Aplikasi & 2 & 0.13 & 0.07 & $0.05^{\mathrm{tn}}$ & 3.89 & 6.93 \\
\hline Lokasi*Aplikasi & 2 & 0.12 & 0.06 & $0.04^{\text {tn }}$ & 3.89 & 6.93 \\
\hline Ulangan*Lokasi*Aplikasi & 12 & 16.07 & 1.34 & $3,784.12^{* *}$ & 1.96 & 2.58 \\
\hline Hormon & 4 & 0.45 & 0.11 & $317.21^{* *}$ & 2.57 & 3.74 \\
\hline Hormon*Lokasi & 4 & 0.08 & 0.02 & $53.94^{* *}$ & 2.57 & 3.74 \\
\hline Hormon*Aplikasi & 8 & 0.65 & 0.08 & $229.49^{* *}$ & 2.14 & 2.91 \\
\hline Hormon*Lokasi*Aplikasi & 8 & 0.34 & 0.04 & $121.77^{* *}$ & 2.14 & 2.91 \\
\hline Galat & 48 & 0.02 & 0 & & & \\
\hline Total Terkoreksi & 89 & 17.86 & & & & \\
\hline
\end{tabular}

Tabel 6. Rata-rata Laju Tumbuh Relatif $\left(\mathrm{g} \mathrm{g}^{-1}\right.$ minggu $\left.^{-1}\right)$ Masing-masing Perlakuan Yang Di Tanam Di Kedua Wilayah Berbeda Berdasarkan Ketinggian Tempat Berbeda

\begin{tabular}{|c|c|c|c|c|c|c|c|c|c|}
\hline \multirow{2}{*}{$\begin{array}{l}\text { Hor } \\
\text { mon }\end{array}$} & \multicolumn{3}{|c|}{ Cirebon } & \multirow{2}{*}{$\begin{array}{c}\text { Rerata } \\
\text { Hormon } \\
\text { (Lokasi } \\
\text { 1) }\end{array}$} & \multicolumn{3}{|c|}{ Jatinangor } & \multirow{2}{*}{$\begin{array}{c}\text { Rerata } \\
\text { Hormon } \\
\text { (Lokasi } \\
\text { 2) }\end{array}$} & \multirow{2}{*}{$\begin{array}{c}\text { Rerata } \\
\text { Hormon } \\
(\mathbf{M} 1+\mathbf{M})\end{array}$} \\
\hline & $\mathbf{X}_{1}$ & $\mathbf{X}_{2}$ & $\mathbf{X}_{3}$ & & $\mathbf{X}_{1}$ & $\mathbf{X}_{2}$ & $\mathbf{X}_{3}$ & & \\
\hline $\mathrm{S}_{0}$ & $0.47^{\mathrm{ij}}$ & $0.50^{\text {fghij }}$ & $0.52^{\text {efghi }}$ & $0.50^{\mathrm{d}}$ & $0.59^{\mathrm{cd}}$ & $0.44 \mathrm{j}$ & $0.44 \mathrm{i}$ & $0.49^{\mathrm{d}}$ & $0.50^{c}$ \\
\hline $\mathrm{S}_{1}$ & 0.54 defgh & 0.49ghij & 0.49ghij & $0.51^{\mathrm{d}}$ & 0.49ghij & $0.61^{\mathrm{c}}$ & $0.59^{\mathrm{cd}}$ & $0.57^{\mathrm{c}}$ & $0.54^{\mathrm{b}}$ \\
\hline $\mathrm{S}_{2}$ & $0.47^{\mathrm{ij}}$ & $0.57^{\mathrm{cde}}$ & $0.48^{\mathrm{hij}}$ & $0.51^{\mathrm{d}}$ & $0.56^{\text {cdef }}$ & $0.46^{\mathrm{ij}}$ & $0.50^{\text {fghij }}$ & $0.51^{\mathrm{d}}$ & $0.51^{\mathrm{c}}$ \\
\hline $\mathrm{S}_{3}$ & $0.47^{\mathrm{ij}}$ & $0.47^{\mathrm{ij}}$ & $0.55^{\mathrm{defg}}$ & $0.50^{\mathrm{d}}$ & 0.49ghij & $0.52^{\text {efghi }}$ & $0.44 i$ & $0.49^{\mathrm{d}}$ & $0.49^{c}$ \\
\hline $\mathrm{S}_{4}$ & $0.48^{\text {hij }}$ & $0.51^{\text {efghi }}$ & $1.23^{\mathrm{a}}$ & $0.74^{\mathrm{a}}$ & $0.57^{\text {cde }}$ & $0.57^{\mathrm{cde}}$ & $0.71^{\mathrm{b}}$ & $0.62^{\mathrm{b}}$ & $0.68^{a}$ \\
\hline $\mathrm{S}_{0}$ & $0.53^{\mathrm{bc}}$ & $0.47^{\mathrm{f}}$ & $0.48^{\mathrm{ef}}$ & & & & & & \\
\hline $\mathrm{S}_{1}$ & $0.52^{\text {bcde }}$ & $0.55^{\mathrm{b}}$ & $0.54^{\mathrm{b}}$ & & & & & & \\
\hline $\mathrm{S}_{2}$ & $0.52^{\text {bcde }}$ & $0.52^{\text {bcde }}$ & 0.49 def & & & & & & \\
\hline $\mathrm{S}_{3}$ & $0.48^{\mathrm{ef}}$ & $0.50^{\text {cdef }}$ & $0.50^{\text {cdef }}$ & & & & & & \\
\hline $\mathrm{S}_{4}$ & $0.53^{\mathrm{bcd}}$ & $0.54^{\mathrm{b}}$ & $0.97^{\mathrm{a}}$ & & & & & & \\
\hline
\end{tabular}

Dari hasil uji lanjut menunjukkan bahwa dosis $\mathrm{S}_{4}\left(400 \mathrm{mg} \mathrm{L}{ }^{-1}\right)$ menunjukkan nilai laju tumbuh relatif yang paling tinggi dibanding dengan dosis lainnya. Perlakuan terbaik ada di lokasi Cirebon dengan nilai laju tumbuh relatif mencapai $0,74\left(\mathrm{~g} \mathrm{~g}^{-1}\right.$ minggu $^{-1}$ ) (Tabel 6). Dari hasil analisis menunjukkan bahwa perlakuan terbaik ada pada sitokinin BAP $_{4}\left(400 \mathrm{mg} \mathrm{L}^{-1}\right)$ dan kultivar jarak pagar IP-3M dengan dosis FMA 10 gram di lokasi Cirebon (1,23 $\mathrm{g} \mathrm{g}^{-1}$ minggu $\left.^{-1}\right)$. Di karenakan terdapat interaksi antara sitokinin BAP dan kultivar jarak pagar dengan dosis FMA terbaik maka dapat ditentukan kombinasi terbaik antara sitokinin BAP dan kultivar jarak pagar dengan dosis FMA terbaik yaitu pada $\mathrm{S}_{4}$ (400 $\mathrm{mg} \mathrm{L}^{-1}$ ) dengan $\mathrm{X}_{3}$ (kultivar IP-3M dengan dosis FMA terbaik), kondisi tersebut dimungkinkan karena pada dosis kombinasi terbaik tersebut mengakibatkan inokulasi sangat efektif, sebab optimalisasi dalam pemanfaatan karbohidrat dari tanaman dan meningkatkan tingkat infeksi FMA dalam memperoleh energi dari tanaman inang. FMA memerlukan energi besar. Pembentukan, pemeliharaan, dan berfungsinya struktur mikoriza dapat menyerap 5-20\% fotosintat. Sejumlah tahapan konsumsi energi diperlukan dalam proses suplai $\mathrm{P}$ ke tanaman inang (misalnya serapan P oleh fungi, konversi menjadi polyphosphate, transport dan aliran ke tanaman). Untuk mendapatkan suatu manfaat memerlukan energi yang lebih besar sehingga memaksimalkan kemampuan organisme (Suherman, 2011).

\section{d. Rata-rata Laju Asimilasi Bersih $(L A B)$}

Laju asimilasi bersih (LAB) merupakan peningkatan rata-rata produksi bersih aparat fotosintesis tanaman pada setiap satuan luas daun pada periode tertentu (Gardner et al., 1985). Hasil analisis menunjukkan bahwa terdapat perbedaan 
yang sangat nyata untuk variabel laju asimilasi bersih pada masing-masing dosis sitokinin BAP, selain itu terjadi interaksi antara sitokinin BAP dan lokasi, sitokinin dan kultivar jarak pagar dengan dosis FMA terbaik, dan sitokinin BAP ; lokasi ; kultivar jarak pagar dengan dosis FMA terbaik. Hasil analisis menunjukkan bahwa koefisien keragaman variabel rata-rata laju asimiliasi bersih sebesar 0,07\%, hal ini menunjukkan bahwa data memiliki tingkat eror yang rendah dan sehingga data ratarata laju asimiliasi bersih dapat dipertanggungjawabkan merujuk pada Harjosuwono, dkk. (2011:12) apabila koefisien keragaman di bawah 20\% maka data dapat dipertanggungjawabkan.

Tabel 7. Hasil Analsis Sidik Ragam Terhadap Laju Asimilasi Bersih $\left(\mathrm{g} \mathrm{cm}^{-2} \mathrm{minggu}^{-1}\right)$ Yang Di Tanam Di Kedua Wilayah Berbeda Berdasarkan Ketinggian Tempat Berbeda

\begin{tabular}{|c|c|c|c|c|c|c|}
\hline \multirow{2}{*}{ Sumber } & \multirow{2}{*}{$\mathrm{db}$} & \multirow{2}{*}{ JK } & \multirow{2}{*}{ K'T } & \multirow{2}{*}{ FHitung } & \multicolumn{2}{|c|}{ FTabel } \\
\hline & & & & & $5 \%$ & $1 \%$ \\
\hline Lokasi & 1 & $30,265,468.12$ & $30,265,468.12$ & $11,049.43^{* *}$ & 4.75 & 9.33 \\
\hline Aplikasi & 2 & $863,033.18$ & $431,516.59$ & $157.54^{* *}$ & 3.89 & 6.93 \\
\hline Lokasi*Aplikasi & 2 & $403,433.27$ & $201,716.64$ & $73.64^{* *}$ & 3.89 & 6.93 \\
\hline Ulangan*Lokasi*Aplikasi & 12 & $32,869.18$ & $2,739.10$ & $6,376.67^{* *}$ & 1.96 & 2.58 \\
\hline Hormon & 4 & $1,038,101.05$ & $259,525.26$ & $604,179.40^{* *}$ & 2.57 & 3.74 \\
\hline Hormon*Lokasi & 4 & $833,882.51$ & $208,470.63$ & $485,323.31^{* *}$ & 2.57 & 3.74 \\
\hline Hormon*Aplikasi & 8 & $890,010.79$ & $111,251.35$ & $258,995.11^{* *}$ & 2.14 & 2.91 \\
\hline Hormon*Lokasi*Aplikasi & 8 & $1,916,059.83$ & $239,507.48$ & $557,577.65^{* *}$ & 2.14 & 2.91 \\
\hline Galat & 48 & 20.62 & 0.43 & & & \\
\hline Total Terkoreksi & 89 & $36,242,878.55$ & & & & \\
\hline
\end{tabular}

Tabel 8. Rata-rata Laju Asimilasi Bersih $\left(\mathrm{g} \mathrm{cm}^{-2}\right.$ minggu $\left.^{-1}\right)$ Masing-masing Perlakuan Yang Di Tanam Di Kedua Wilayah Berbeda Berdasarkan Ketinggian Tempat Berbeda

\begin{tabular}{|c|c|c|c|c|c|c|c|c|c|}
\hline \multirow[b]{2}{*}{$\begin{array}{l}\text { Hor } \\
\text { mon }\end{array}$} & \multicolumn{3}{|c|}{ Cirebon } & \multirow{2}{*}{$\begin{array}{l}\text { Rerata } \\
\text { Horm } \\
\text { on(Lo } \\
\text { kasi 1) }\end{array}$} & \multicolumn{3}{|c|}{ Jatinangor } & \multirow{2}{*}{$\begin{array}{c}\text { Rerata } \\
\text { Hormon } \\
\text { (Lokasi } \\
2)\end{array}$} & \multirow[b]{2}{*}{$\begin{array}{c}\text { Rerata } \\
\text { Hormo } \\
\text { n (M1+) }\end{array}$} \\
\hline & $\mathbf{X}_{1}$ & $\mathbf{X}_{2}$ & $\mathrm{X}_{3}$ & & $\mathbf{X}_{1}$ & $\mathbf{X}_{2}$ & $\mathrm{X}_{3}$ & & \\
\hline $\mathrm{S}_{0}$ & $1,177.61^{\mathrm{i}}$ & $1,446.74^{\mathrm{h}}$ & $1,525.51^{\mathrm{g}}$ & $1,383.29^{d}$ & $508.35^{j}$ & $421.76^{\mathrm{m}}$ & $187.46 \mathrm{q}$ & $372.53^{\mathrm{h}}$ & $877.91^{d}$ \\
\hline $\mathrm{S}_{1}$ & $2,263.49^{\mathrm{a}}$ & $1,889 \cdot 68^{c}$ & $1,400.69^{i}$ & $1,851.29^{\mathrm{a}}$ & $301.41^{\mathrm{n}}$ & $458.47^{\mathrm{k}}$ & $478.16^{\mathrm{j}}$ & $412.68^{g}$ & $1,131.99^{a}$ \\
\hline $\mathrm{S}_{2}$ & $1,785.30^{\mathrm{e}}$ & $1,895.71^{b}$ & $1,190.13^{i}$ & $1,623.71^{b}$ & $431.66^{1}$ & $164.68^{r}$ & $246.62^{p}$ & $280.99{ }^{i}$ & $952.35^{c}$ \\
\hline $\mathrm{S}_{3}$ & $1,268.56^{\mathrm{i}}$ & $1,180.58^{\mathrm{i}}$ & $1,445.11^{\mathrm{h}}$ & $1,298.08^{\mathrm{e}}$ & $407.54^{\mathrm{m}}$ & $299.59^{n}$ & $293.16^{\circ}$ & $333.43^{\mathrm{i}}$ & $815.76^{\mathrm{e}}$ \\
\hline $\mathrm{S}_{4}$ & $1,714.87^{f}$ & $1,855.87^{d}$ & $953.89^{\mathrm{i}}$ & $1,508.21^{\mathrm{c}}$ & $488.84 j$ & $476.42^{j}$ & $432.60^{1}$ & $465.96^{\mathrm{f}}$ & $987.08^{b}$ \\
\hline $\mathrm{S}_{0}$ & $842.98^{\mathrm{k}}$ & $934.25^{\mathrm{h}}$ & $856.49 j$ & & & & & & \\
\hline $\mathrm{S}_{1}$ & $1,282.45^{\mathrm{a}}$ & $1,174.08^{b}$ & $939.43 \mathrm{~g}$ & & & & & & \\
\hline $\mathrm{S}_{2}$ & $1,108.48^{\mathrm{d}}$ & $1,030.20^{\mathrm{f}}$ & $718.38^{n}$ & & & & & & \\
\hline $\mathrm{S}_{3}$ & $838.05^{1}$ & $740.09^{\mathrm{m}}$ & $869.14^{\mathrm{i}}$ & & & & & & \\
\hline $\mathrm{S}_{4}$ & $1,101.86^{\mathrm{e}}$ & $1,166.15^{\mathrm{c}}$ & $693.25^{\circ}$ & & & & & & \\
\hline
\end{tabular}

Dari hasil uji lanjut menunjukkan bahwa dosis $\mathrm{S}_{1}\left(100 \mathrm{mg} \mathrm{L}^{-1}\right)$ menunjukkan nilai laju asimilasi bersih yang paling tinggi dibanding dengan dosis lainnya. Perlakuan terbaik ada di lokasi Cirebon dengan nilai laju asimilasi bersih mencapai 1.851,29 ( $\mathrm{g}$ $\mathrm{cm}^{-2}$ minggu ${ }^{-1}$ ) (Tabel 8). Dari hasil analisis menunjukkan bahwa perlakuan terbaik ada pada sitokinin BAP $\mathrm{S}_{1}\left(100 \mathrm{mg} \mathrm{\textrm {L } ^ { - 1 }}\right)$ dan kultivar jarak pagar IP-3P dengan dosis FMA 5 gram di lokasi Cirebon $(2.263,49 \mathrm{~g}$ $\mathrm{cm}^{-2}$ minggu $\left.{ }^{-1}\right)$. Percepatan LAB akibat perlakuan FMA dimungkinkan karena FMA meningkatkan infeksi dan konsentrasi sitokinin BAP. Di karenakan terdapat interaksi antara sitokinin BAP dan kultivar jarak pagar dengan dosis FMA terbaik maka dapat ditentukan kombinasi terbaik antara sitokinin BAP dan kultivar jarak pagar dengan dosis FMA terbaik yaitu pada $\mathrm{S}_{1}\left(100 \mathrm{mg} \mathrm{L}^{-1}\right)$ dengan $\mathrm{X}_{1}$ (kultivar IP-3P dengan dosis FMA terbaik). Peningkatan LAB pada tahap awal partumbuhan, terjadi karena seiring dengan peningkatan jumlah daun pada tahap awal yang memungkinkan semakin meningkatnya kemampuan tanaman dalam mengabsorpsi cahaya matahari, sehingga 
berjalan tinggi dan menghasilkan fotosintat yang tinggi pula. Nilai LAB yang tinggi pada fase vegetatif aktif disebabkan karena laju asimilasi $\mathrm{CO}_{2}$ biasanya tinggi sehingga produksi fotosintat lebih banyak. Kondisi tersebut akan meningkatkan bobot tanaman dibanding fase generatif (Bonfante et al., 1995). Pada fase vegetatif fotosintat yang dihasilkan banyak digunakan untuk penambahan luas daun (Dedi Natawijaya, 2018). Selain itu, nilai LAB dipengaruhi oleh banyak faktor seperti temperature, cahaya, $\mathrm{CO}_{2}$, air, umur tanaman, unsur hara dan kandungan klorofil (Gardner, 1991). Selain itu, LAB suatu tanaman juga dipengaruhi oleh jenis tanaman, cahaya, kelembapan serta lingkungan fisik, biologi, dan kimia tanah.

\section{e. Nisbah Pupus Akar (NPA)}

Nisbah pupus akar (NPA) atau shoot root ratio (SRR) merupakan perbandingan antara bobot kering bagian atas tanaman dengan bobot kering bagian bawah (akar). Bobot kering ini diperoleh dengan cara mengeringkan bagian tanaman dalam oven dengan temperatur $80^{\circ} \mathrm{C}$ sampai bobotnya konstan. Semakin besar
NPA, berarti laju penambahan bahan kering bagian atas lebih besar. Hal tersebut berarti juga bahwa pertumbuhan bagian atas dan partisi fotosintat lebih mengarah ke bagian organ tersebut. Demikian sebaliknya, bila NPA kecil maka pertumbuhan dan partisi fotosintat banyak ditujukan ke bagian akar tersebut. Dalam kondisi normal di alam, pada umumnya pertumbuhan dan partisi fotosintat hampir selalu diarahkan ke bagaian atas (pupus), sehingga nilai NPA selalu lebih besar dari 1.

Hasil analisis menunjukkan bahwa terdapat perbedaan yang sangat nyata untuk variabel nisbah pupus akar pada masing-masing dosis sitokinin BAP, selain itu terjadi interaksi antara sitokinin BAP dan lokasi, sitokinin dan kultivar jarak pagar dengan dosis FMA terbaik, dan sitokinin BAP ; lokasi ; kultivar jarak pagar dengan dosis FMA terbaik. Hasil analisis menunjukkan bahwa koefisien keragaman $1,40 \%$ sangat rendah dengan tingkat eror yang rendah sehingga apabila koefisien keragaman di bawah 20\% maka data dapat dipertanggungjawabkan (Harjosuwono, dkk. (2011:12).

Tabel 9. Hasil Analsis Sidik Ragam Terhadap Nisbah Pupus Akar (NPA) Yang Di Tanam Di Kedua Wilayah Berbeda Berdasarkan Ketinggian Tempat Berbeda

\begin{tabular}{lcccccc}
\hline \multicolumn{1}{c}{ Sumber } & db & JK & KT & FHitung & \multicolumn{2}{c}{ FTabel } \\
\cline { 5 - 7 } Lokasi & 1 & 328.6 & 328.6 & $1,848.36^{* *}$ & 4.75 & $\mathbf{1 \%}$ \\
Aplikasi & 2 & 125.52 & 62.76 & $353.02^{* *}$ & 3.89 & 6.93 \\
Lokasi*Aplikasi & 2 & 138.93 & 69.47 & $390.74^{* *}$ & 3.89 & 6.93 \\
Ulangan*Lokasi*Aplikasi & 12 & 2.13 & 0.18 & $16.00^{* *}$ & 1.96 & 2.58 \\
Hormon & 4 & 194.23 & 48.56 & $4,370.25^{* *}$ & 2.57 & 3.74 \\
Hormon*Lokasi & 4 & 205.57 & 51.39 & $4,625.42^{* *}$ & 2.57 & 3.74 \\
Hormon*Aplikasi & 8 & 211.25 & 26.41 & $2,376.56^{* *}$ & 2.14 & 2.91 \\
Hormon*Lokasi*Aplikasi & 8 & 256.71 & 32.09 & $2,888.04^{* *}$ & 2.14 & 2.91 \\
Galat & 48 & 0.53 & 0.01 & & & \\
Total Terkoreksi & 89 & $1,463.49$ & & & & \\
\hline kk=1.40\% & & & & & & \\
\hline
\end{tabular}


Tabel 10. Rata-rata Nisbah Pupus Akar (NPA) Masing-masing Perlakuan Yang Di Tanam Di Kedua Wilayah Berbeda Berdasarkan Ketinggian Tempat Berbeda

\begin{tabular}{|c|c|c|c|c|c|c|c|c|c|}
\hline \multirow{2}{*}{$\begin{array}{l}\text { Hor } \\
\text { mon }\end{array}$} & \multicolumn{3}{|c|}{ Cirebon } & \multirow{2}{*}{$\begin{array}{c}\text { Rerata } \\
\text { Hormon } \\
\text { (Lokasi } \\
\text { 1) }\end{array}$} & \multicolumn{3}{|c|}{ Jatinangor } & \multirow{2}{*}{$\begin{array}{c}\text { Rerata } \\
\text { Hormon } \\
\text { (Lokasi } \\
\text { 2) }\end{array}$} & \multirow{2}{*}{$\begin{array}{c}\text { Rerata } \\
\text { Hormo } \\
\text { n(M1+ } \\
\text { M2) }\end{array}$} \\
\hline & X1 & $\mathrm{X} 2$ & X3 & & X1 & $\mathrm{X} 2$ & X3 & & \\
\hline $\mathrm{SO}$ & $5.35^{\text {no }}$ & $5.25^{\text {nop }}$ & $6.91 \mathrm{gh}$ & $5.84 \mathrm{fg}$ & $7.50^{\mathrm{f}}$ & $19.37^{b}$ & $9.43^{\mathrm{d}}$ & $12.10^{b}$ & $8.97^{b}$ \\
\hline $\mathrm{S} 1$ & $6.27 \mathrm{jk}$ & $4.92 \mathrm{pqr}$ & $4.59 \mathrm{rs}$ & $5.26^{\mathrm{h}}$ & $7.55^{f}$ & $5.761^{\mathrm{m}}$ & $10.06 \mathrm{c}$ & $7.79^{\mathrm{c}}$ & $6.53^{c}$ \\
\hline S2 & $5.39^{\text {no }}$ & $5.19 \mathrm{opq}$ & $5.581^{\mathrm{mn}}$ & $5.39^{\mathrm{h}}$ & $7.81^{\mathrm{ef}}$ & $23.2^{6 a}$ & $10.39^{c}$ & $13.82^{\mathrm{a}}$ & $9.60^{\mathrm{a}}$ \\
\hline S3 & $4.86 \mathrm{qr}$ & $5.54^{\mathrm{mno}}$ & $6.64^{\mathrm{hi}}$ & $5.68^{\mathrm{g}}$ & $6.49^{\mathrm{ij}}$ & $8.02^{\mathrm{e}}$ & $4.47^{\mathrm{s}}$ & $6.33^{e}$ & $6.00^{\mathrm{d}}$ \\
\hline S4 & $5.40^{\text {no }}$ & $6.29^{\mathrm{ij}}$ & $5.93^{\mathrm{kl}}$ & $5.87^{f}$ & $5.53^{\mathrm{mno}}$ & $7.14^{\mathrm{g}}$ & $8.65^{\mathrm{e}}$ & $7.11^{\mathrm{d}}$ & $6.49^{c}$ \\
\hline So & $6.43 \mathrm{~g}$ & $12.31^{b}$ & $8.17^{c}$ & & & & & & \\
\hline S1 & $6.91^{\mathrm{e}}$ & $5.34^{\mathrm{i}}$ & $7.32^{\mathrm{d}}$ & & & & & & \\
\hline $\mathrm{S} 2$ & $6.60^{\mathrm{fg}}$ & $14.23^{a}$ & $7.99 \mathrm{c}$ & & & & & & \\
\hline S3 & $5.68^{h}$ & $6.78^{\mathrm{ef}}$ & $5.56^{\mathrm{hi}}$ & & & & & & \\
\hline $\mathrm{S} 4$ & $5.47^{\mathrm{hi}}$ & $6.71 \mathrm{ef}$ & $7.29 \mathrm{~d}$ & & & & & & \\
\hline
\end{tabular}

Dari hasil uji lanjut menunjukkan bahwa dosis $\mathrm{S}_{2}\left(200 \mathrm{mg} \mathrm{L}^{-1}\right)$ menunjukkan nilai nisbah pupus akar yang paling tinggi dibanding dengan dosis lainnya. Perlakuan terbaik ada di lokasi Jatinangor dengan nilai nisbah pupus akar mencapai 13,82 (Tabel 10). Dari hasil analisis menunjukkan bahwa perlakuan terbaik ada pada sitokinin BAP $\mathrm{S}_{2}\left(200 \mathrm{mg} \mathrm{L}^{-1}\right)$ dan kultivar jarak pagar IP$3 \mathrm{~A}$ dengan dosis FMA 5 gram di lokasi Jatinangor (23,26). Kondisi demikian dapatdipahami karena pada tanaman yang diinokulasi FMA ( $\mathrm{x}_{1}, \mathrm{x}_{2}$, dan $\left.\mathrm{x}_{3}\right)$ pertumbuhan akarnya akan lebih baik dibandingkan dengan tanpa perlakuan FMA. Peneliti sebelumnya juga menemukan bahwa FMA membantu peningkatan pertumbuhan dan fungsi akar. Peningkatan tersebut terlihat pada panjang akar dengan biomassa akar dan FMA. Di karenakan terdapat interaksi antara sitokinin BAP dan kultivar jarak pagar dengan dosis FMA terbaik maka dapat ditentukan kombinasi terbaik antara sitokinin BAP dan kultivar jarak pagar dengan dosis FMA terbaik yaitu pada $\mathrm{S}_{2}$ (200 $\mathrm{mg} \mathrm{L}^{-1}$ ) dengan $\mathrm{X}_{1}$ (kultivar IP-3A dengan dosis FMA terbaik). Jadi pada keadaan $\mathrm{P}$ yang memadai pertumbuhan akar akan lebih baik, sehingga nilai NPA menjadi lebih kecil sedangkan kelebihan $\mathrm{N}$ akan mengakibatkan pertumbuhan tajuk yang besar sehingga nilai NPA menjadi besar (Suherman, 2011).

\section{KESIMPULAN}

Hasil percobaan menunjukkan terdapat pengaruh yang nyata setiap perlakuan dan terjadi interaksi antara perlakuan kombinasi kultivar jarak pagar dan dosis fungi mikoriza arbuskular (FMA) terbaik dengan konsentrasi sitokinin. Di karenakan terdapat interaksi antara sitokinin BAP dan kultivar jarak pagar dengan dosis FMA terbaik maka dapat ditentukan kombinasi terbaik antara sitokinin BAP dan kultivar jarak pagar dengan dosis FMA terbaik di kedua lokasi yaitu pada $\mathrm{S}_{3}\left(300 \mathrm{mg} \mathrm{L}^{-1}\right)$ dengan $\mathrm{X}_{3}$ (kultivar IP-3M) untuk luas daun, $\mathrm{S}_{3}(300$ $\mathrm{mg} \mathrm{L} \mathrm{L}^{-1}$ ) dengan $\mathrm{X}_{2}$ (kultivar IP-3A) untuk nisbah luas daun, $\mathrm{S}_{4}\left(400 \mathrm{mg} \mathrm{L}^{-1}\right)$ dengan $\mathrm{X}_{3}$ (kultivar IP-3M) untuk rata-rata laju tumbuh (LTR), $\mathrm{S}_{1}\left(100 \mathrm{mg} \mathrm{L}^{-1}\right)$ dengan $\mathrm{X}_{1}$ (kultivar IP-3P) untuk rata-rata laju asimilasi bersih (LAB), $\mathrm{S}_{2}\left(300 \mathrm{mg} \mathrm{L}^{-1}\right)$ dengan $\mathrm{X}_{1}$ (kultivar IP-3P) untuk nisbah pupus akar (NPA).

\section{DAFTAR PUSTAKA}

Bonfante, P., and V. Bianciatto. 1995. Presymbiotic versus symbiotic phase in arbuscular endomycorrhizae fungi. Motphologi and cytology. P. 229247. In A. Varma and B. Hock (ed.). Mycorrhiza, structure, fungtion, molecular biology and biotechnology. Springer Verlag, Berlin. 
Brundrett, M., N. Bougher, B. Dell, T. Grove, Malajck. 1994. Working With Mycorrhizas In Forestry and Agriculture. International Mycorrhizal Workshop, China.

Cucu Suherman VZ. 2011. Peningkatan Pertumbuhan, Hasil Dan Rendemen Minyak Jarak Pagar (Jatropha curcas Linn) Melalui Aplikasi Fungi Mikoriza Arbuskula Dan Pupuk Fosfat Pada Inceptisol Jatinangor. Disertasi. Program Pascasarjana Unpad. Bandung.

Dedi Natawijaya. 2018. Percepatan Pertumbuhan Benih Aren (Arenga Pinnata (Wurmb.) Merr.) Melalui Perendaman Dan Pelukaan Biji. Jurnal Siliwangi Seri Sains dan Teknologi Vol.4. No.1, 2018.

Gardner, F.P., R.B. Pearce, and R.L. Mitchell.1985. Physicology on crop plants. The Iowa State University Press.

Gardner, F.P., R.B. Pearce dan R.L.Mitchell. 1991. Fisiologi Tanaman Budidaya. UI Press. Jakarta.

Harjosuwono, B. A., Arnata, I. W. \& Puspawati, G. A. K. D. (2011). Rancangan Percobaan Teori, Aplikasi SPSS dan Excel. Malang: Lintas Kata Publishing.
Mulyani, A., F. Agus, dan David Allelorung. 2008. Potensi Sumber Daya Lahan Untuk Pengembangan Jarak Pagar (Jatropha curcas L.) Di Indonesia. Jurnal Litbang Pertanian, 25(4).

Rahmawaty R., Muhammad A., Bahrudin. 2015. Aplikasi Bakteri Pelarut Fosfat, Bakteri Penambat Nitrogen Dan Mikoriza Terhadap Pertumbuhan Tanaman Cabai (Capsicum Annum L.). Jurnal Agrotekbis 3 (3) : 316 - 328 ISSN : 2338-3011, Juni 2015.

Schmidt, F.H. and J.H.A. Ferguson. 1951. Rainfall Types Based on Wet and Dry Period Ration for Indonesia with Western New Guinea. Verhandelingen NO. 42. Kementrian Perhubungan. Djawatan Meteorologi and Geofisika, Djakarta.

Singh, R.K. and Chaudhary, B.D. (1979) Biometrical Methods in Quantitative Genetic Analysis. Biometrical Methods in Quantitative Genetic Analysis.

Smith, S.E. and D. Read. 2008. Mycorhiza Sybiosis. Academic Press. New York. 